\title{
Sustainability in Architecture of Zbigniew Abrahamowicz
}

\author{
Tomasz Sachanowicz
}

West Pomeranian University of Technology in Szczecin, Żołnierska 50, 71-210 Szczecin, Poland

Corresponding Author Email: tomasz.sachanowicz@ zut.edu.pl

https://doi.org/10.18280/ijdne.150111

Received: 2 September 2019

Accepted: 11 February 2020

\section{Keywords:}

architecture in Szczecin, continuity, polish architecture, PRL architecture, sustainable architecture, sustainable building, sustainable design, Zbigniew Abrahamowicz.

\begin{abstract}
Architect Zbigniew Abrahamowicz (1938-1990) is crucial figure for post war history of architecture in Polish city of Szczecin. However, his realized body of work is significant and spans from single family houses through public spaces to larger public buildings like churches and amphitheater it was not studied enough and not only in my opinion it needs thorough and systematical analysis. His buildings draw from modernist ideas and vocabulary but are rooted in local tradition and thus always context friendly. Love of nature is clear in his design approach. Abrahamowicz was outstandingly prolific architect and there is a lot of built evidence of his activity but as he never spoke or wrote about his ideas and work, it lacks theoretical reflection. Almost 30 years after his passing it is applicable to study his heritage and draw conclusions from it. Paper presents tracing of sustainable aspect in Zbigniew Abrahamowicz built work through analysis of design ethos, contexts, forms (compactness of volumes, elevations openings ratio), building techniques, materials used and new uses and alterations introduced. Methodology applied was defined by available materials: research based on archival query (original design drawings, texts on Abrahamowicz architecture published in local newspapers and countrywide magazines), interviews (with his friends and co-workers), analysis of plans and elevations of his buildings, interpretation of gathered material. To conclude, there is at least two general ways of understanding sustainability: one is about keeping ecological equilibrium and the other is about continuity. In times of Abrahamowicz professional activity (1965-1990) term 'sustainability' was not present in architectural discourse in Poland but we can find the notion of continuity in any of his work. His houses and especially public buildings are still serving its purposes, some of them are upgraded and, what is perhaps more important, are popular and loved by people of Szczecin.
\end{abstract}

\section{INTRODUCTION}

Zbigniew Abrahamowicz (1938-1990) was born in Chodorów near Lwów (now Ukraine) in 1938. He spent his childhood in Stargard Szczeciński. he studied architecture in Gdansk Polytechnic (1959-1964), and undertook his first work as inspector in Architecture and Planning Department of City Council of Szczecin in 1964. Since then, he never parted with Szczecin or the Council. In ten years period, sharing his time between career of the office clerk and prolific designer he has achieved the position of one of the most famous, respectable and sought after architects in the city of Szczecin. His realized projects represent rich repertoire of forms, variety of themes (from fountains, pavilions, through single family houses to large scale public buildings like churches and amphitheater, to finish with public space project in the urban center of Szczecin called The Fountain Alley. All the projects he touched have traces of his intuitive sense of context and proportion, lightness, ease and fluency in syntax of architectural language and simply flair. Professor A.M. Szymski expert on architecture of Szczecin wrote: separate and remarkable attention should be paid to individual design activity of Zbigniew Abrahamowicz... emphasizing the sensitivity and distinctive for whole oeuvre of this architect appositeness, right measure or proper sense of space [1]. Briefly referring to the houses designed by Abrahamowicz he calls him a founder of his own distinctive style as well as forerunner of postmodernism on a local scale. Art historians put Abrahamowicz amidst the most important architects active in Szczecin after 1945 [2]. His Summer Theatre in Kasprowicz Park (Figure 1) and St. Cross Church (Figure 2) in the green neighborhood of single family houses in Szczecin Pogodno prewar garden city estate are the classics of Szczecin's post war architecture, flagship buildings of the 70s and popular landmarks (they often appear in the top 10 buildings surveys) of Szczecin. In his time, Zbigniew Abrahamowicz was the most famous architect in Szczecin. His realized buildings were highly anticipated and widely discussed by the public and local media. He enjoyed unprecedented sympathy and esteem of his professional environment. One of his colleagues referred to him as great individualist in the era of uniformity [3]. Local press had mentioned him and his current projects frequently. A set of his projects was published in country-wide professional magazine - Polish Architects Association (SARP) 'Architektura', no 9-10, Warszawa, 1977, under the title 'Retro festiwal Zbigniewa Abrahamowicza' [4]. According to Jozef Szkwarek - structural engineer who cooperated with Abrahamowicz on two of his largest projects: St. Cross Church and amphitheater in Szczecin's Kasprowicz Park - he was a great craftsman: nobody would say a bad word about him, because it was obvious - nobody have done anything better than him-people knew that he have done and accomplished things which nobody else could have done or haven 't yet tried to do back then. [4] He knew a lot about the art of building and 
building materials. His favorite material was timber, which he loved to work with in his workshop. It is crucial to mention difficult socio-economic conditions for building in Poland under communist government (1945-1989), especially scarcity of means and shortages of building materials, limited or lack of access to modern building technologies and equipment or even financing mechanisms. The main client for collective housing buildings and housing estates as well as for public buildings was the state. It is only in the early seventies when government ban of building was removed from it the Catholic Church entered the stage as client for plethora of brand-new church buildings in the coming 30 years. (For more info on polish modern churches, see project Architecture of the VII day [5]). Designing and building individual single-family houses was an exclusive, almost niche activity as most of houses were built based on standard, catalogue designs.

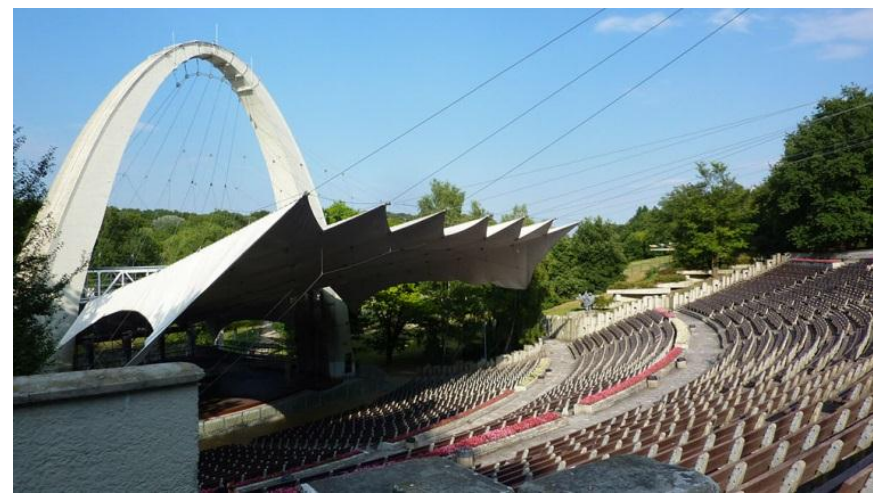

Figure 1. Summer Theatre in Kasprowicz's Park in Szczecin (Photo: T. Sachanowicz)

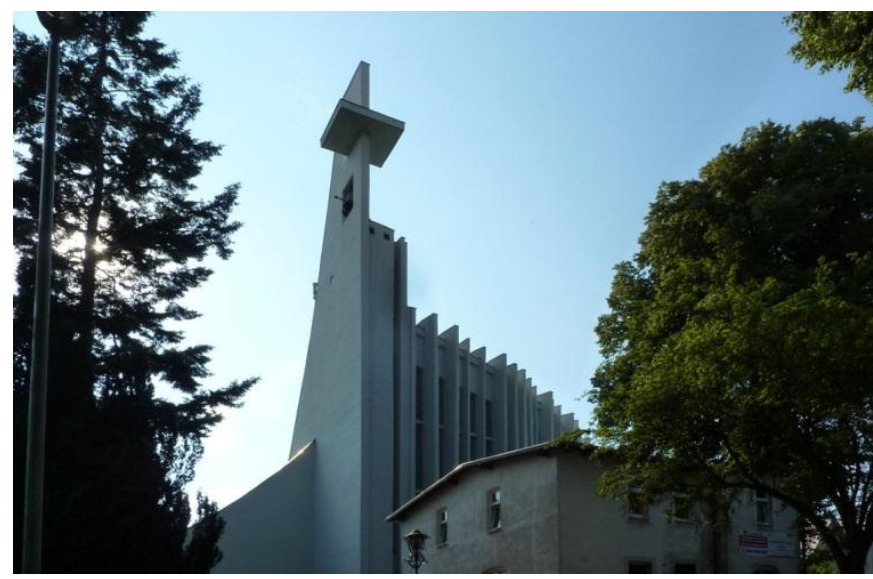

Figure 2. St. Cross Church in Szczecin (Photo: T.Sachanowicz)

\section{LOVE OF NATURE}

There is a group of architects for whom Nature is the highest source of unmatched beauty and they take it as a reference point for their own work. They struggle to discover the order, which exist in Nature's creations and try to conceive architecture which continues tradition and is a result of evolution. One of those architects was undoubtedly Finnish master of twentieth century architecture Alvar Aalto. Witold Rybczyński wrote: Aalto was a modernist who relied heavily on his intuition and love of Nature I would add [6]. Alto was undoubtedly one of Abrahamowicz's masters although he draws inspiration from work of Le Corbusier as well. Analyzing the whole oeuvre of Abrahamowicz one finds more parallels to the work of Finnish master of this more humanistic, softer and warmer - inspired by nature in contrast to one derived from fascination with machines, therefore, colder and drier (promoted by Le Corbusier) version of modernism. Similarities go even further when you consider love of nature embodied in the work of both architects resulting in blending into the landscape as well as preference for soft, organic forms and use of timber or brick - traditional materials which require human hand, touch of a skilled craftsman to be put in their place in the structure of a building. Although he used the language of modernist architecture, he did it with freedom, full of creativity, trying to achieve rather more picturesque effect of the whole than to introduce cold, uncompromised order of things. Love of nature is clear in his design approach or philosophy. From the relations of his family, friends and clients Abrahamowicz knew a lot about plants and birds and other animals. He enjoyed walking, he never got a car, he just cycled or walked. Very often, he walked with his indispensable companion a dachshund called Myk. There are even some perspective drawings by Abrahamowicz presenting designs of houses on which one can find a small dachshund somewhere around. Abrahamowicz even wrote some poems in which nature took large part. He painted flowers. His house in the Artists' Colony is in the vicinity of the largest park in Szczecin. He really enjoyed closeness to Nature.

\section{CONTEXTS}

Main urban area of Abrahamowicz's architectural activity are two districts of Szczecin: Pogodno and Łękno. Those districts were established in the second half of nineteen century and in the beginning of twentieth century. They consist mainly of housing buildings and were in fact designed as villa districts for the Stettin elites, with modern (back then) ideas of Deutches Werkbund movement and English examples of garden cities. They are therefore areas full of trees, the biggest city park - Kasprowicz's Park is within the borders of Łękno, with the variety of recreational spaces as well as cultural and sports venues. Two of his largest buildings are in fact extensions of, or expansions of objects that were there before and served the same purpose, but became too small for growing population of developing city of Szczecin. First one is the amphitheater also known as Summer Theatre in Kasprowicz's Park, which was built on a slope of a hill previously occupied by a smaller, more private prewar amphitheater. The convenient location in the natural concavity of the slope, between Lake Rusałka and the main park avenue (ul. Fałata) resulted in minimal interference with the natural terrain while shaping the arch-bent, terraced rows of seats for the audience. The auditorium is flanked by reinforced concrete cascades of fountains and dynamic, organic retaining walls formed as landscape architecture fit into the escarpment that forms the basis of its location [1].

The other - St. Cross Church in Wieniawskiego Street was an extension of a smaller church designed by Werner Straube and built in 1929-30 [7]. In the second half of XX century population of the area grew so much that the post-German, pre-war church became too small and the congregation started to look for ways of extending it. The only way of doing it was to build another, bigger church next to existing church. The commission went to Abrahamowicz, as he was already famous 
for original ideas and because of his position in the council that could help with the procedures of planning permission. New structure practically swallowed the existing church covering it with a new roof and hiding its original façade behind a new, concrete wall of bell tower.

Another extension project was the entrance part to Wedding Palace on Mickiewicz Street (Figure 3). This modern structure incorporated or generously embraced with its cornice part a birch-tree, which was growing on the site. The tree could be easily removed - back then nobody would hesitate to cut it down without any consideration, but provision for it was made early in the design stage.

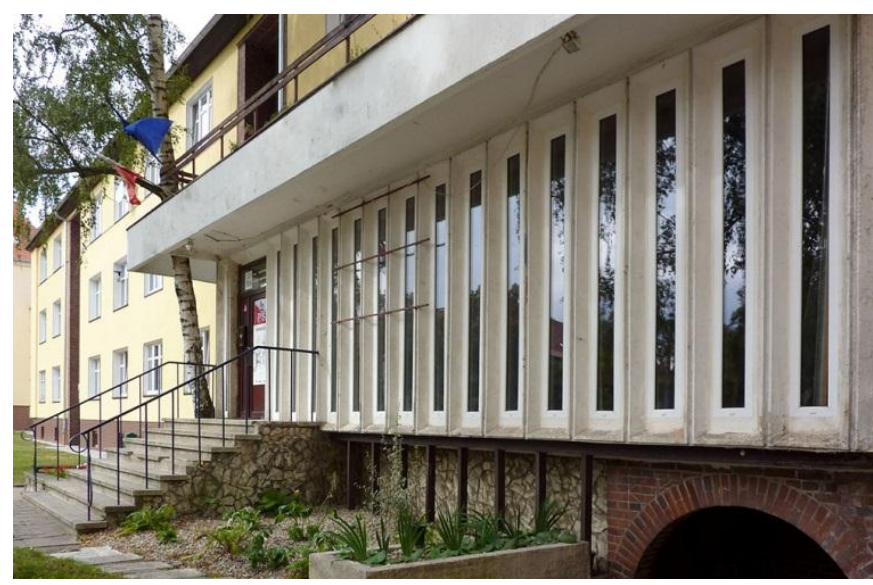

Figure 3. Former Wedding Palace in Szczecin. Building embracing a tree (Photo: T. Sachanowicz)

\section{BUILDING TECHNIQUES AND MATERIALS USED}

Abrahamowicz was gifted, well-educated and became a craftsman in his chosen profession. There are stories about him designing things on site, discussing things with builders, and drawing details directly on the walls of currently constructed building. One of his friends - architect Karol Krzątała reports that once he was building his own house and had a problem with constructing a difficult dormer, he went for advice to Abrahamowicz, who lived in his neighborhood. Abrahamowicz immediately took out some paper, some twine, pencils and started drawing that very detail in one to one scale and explained the detail to his friend. Another colleague said that he knew traditional building techniques very well and his favorite was timber [8].

Primarily his houses were built in most common and locally resourced traditional masonry technique with timber structure, steep roofs covered with ceramic roof tiles of different types, external walls were rendered and painted white, entrance parts or other special parts were clad in stone, brick or timber boards; additional details like handrails, balconies railings etc. were mainly timber or sometimes metalwork. Abrahamowicz often mixed several materials on the elevations of his houses.

His largest realized buildings were cast in in-situ reinforced concrete. The St. Cross Church has a signature concave roof clad with copper. The formwork for the ribbed, fish net-like roof structure was constructed out of timber by a highly skilled group of highlanders-carpenters from the south of Poland. The grand amphitheater arch over the stage is a massive concrete structure and the original roof was in contrast very light made out of fabric.

\section{SUPPORTING ARCHITECTURE WITH ART}

The story of Zbigniew Abrahamowicz is not just about architecture, it involves artistic society of Szczecin in 70s and 80 s of 20th century. Artists, painters, sculptors were colleagues, friends and clients of Abrahamowicz. He designed an Artist's Colony on Chełmoński Street in Szczecin. Jan Stopyra - then mayor of Szczecin gave the plots of land to a group of artists to build their houses there. Abrahamowicz was among them and he became designer of most of the houses. The area was going to be transformed into a kind of open-air gallery with alleys adorned with sculptures and architectural or artistic artefacts. Unfortunately, this artistic landscape never came to life.

Abrahamowicz worked on the project of Summer Theatre within the Plastic Arts Studio in Szczecin. Some of the buildings by Abrahamowicz got artistic decoration - ceramic, colorful mosaic - designed and executed by artist Piotr Wieczorek - friend of Abrahamowicz from university times in Gdańsk. Those mosaics appeared on (already demolished) fountain known as 'Weeping Wall', on the retaining wall of Summer Theatre complex, in the ground floor of several buildings on Wojska Polskiego Avenue and the entrance zone of Actor's House on Arkońska Street. Abrahamowicz regarded himself as an artist. And rightly so - in one lifetime he was a prolific architect, an office clerk, he painted and he happened to write poems. He was a friend, collaborator and a neighbor of artists.

The surroundings of the amphitheater were adorned with outdoor sculptures by artists from Szczecin and Poland. Among the sculptors involved, Maria Łopuch mentions: Anna Paszkiewicz, Leonia Chmielnik, Stanisław Biżek, Ryszard Chachulski, Sławomir and Jakub Lewiński, Mieczysław Welter and Czesław Wronka [9].

Fountain Alley is an outdoor sculpture gallery as well. Whole length of the alley from the Town Hall to Aviators Square, where the alley terminates is punctuated with outdoor sculptures of stone or metal by the local sculptors involved in furnishing the surroundings of amphitheater earlier. Art enriches architecture. It adds to both cultural and social value of buildings and public spaces. Therefore, art helps to make buildings or places that last.

\section{SINGLE FAMILY HOUSES / RETRO-FESTIVAL}

Designed by him - individual but matching the character of Szczecin - white rendered houses with signature arches, brick and timber details, and pitched, ceramic roofs quickly became popular. Then there were architects who tried to copy or emulate architectural language developed by Abrahamowicz. He himself had nothing against those trials. Later this phenomenon was called 'local school of single-family houses design'. In his book on architecture and architects of Szczecin, Prof. A.M. Szymski refers to Abrahamowicz as forerunner of postmodernism in West Pomerania region [2]. Presentation of 12 original single-family houses projects was published in country-wide monthly magazine 'Architektura', no. 9-10/77 and titled 'Zbigniew Abrahamowicz's Retro Festival' [4]. This presentation is affixed with a brief note out of which it is worth to mention the most substantial excerpts: The idea behind this series of projects was the desire to maintain that fin de siècle architectural atmosphere of the city, which is abundant with monuments from the turn of the century.(...) Between those 
buildings angular cubes are sometimes brutally inserted and it would be good if it could be prevented [4]. Above quotation is a conscious statement of continuity and respect for tradition of the place, for the genius loci as it were. Abrahamowicz was the first architect who consciously referred his houses design to the legacy of so-called Recovered Territories. (Szczecin until 1945 was a German city.) Continuity of urban space was of paramount importance to him. He felt that introducing flatroofed cubes between pre-war houses, with steep roofs, covered in roof tiles was something wrong, causing spatial dissonance. So, he made a specific transfer of existing patterns of German architecture. His way of doing it was mixing modernism with local tradition. His buildings draw from modernist ideas and vocabulary but are rooted in local tradition and thus always context friendly. He believed in the structure of the city, so he made modern projects that sustained and developed existing structure of the city, the pattern, the scale and the materials. The best examples of his style are: house for an opera singer and actress Irena Brodzińska on Wojska Polskiego Avenue (Figure 4), houses on Korfanty Street, houses on Wyspiański Street, houses in the Artist's Colony on Chełmoński Street including his own house, which was awarded the second prize in SARP's competition for the best single family house organized for a 50th anniversary of Polish Szczecin in 1995.

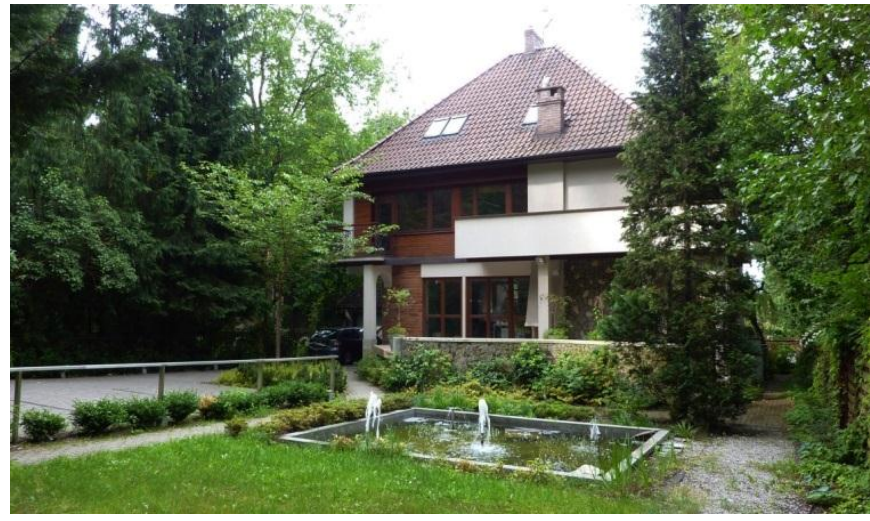

Figure 4. Irena Brodzińska House in Szczecin (Photo: T. Sachanowicz)

Figures 5 and 6 present samples of plans and elevations of houses designed by Abrahamowicz. I decided to make a quick check-up on few samples of his published houses designs. I measured the ground floor plans areas and wall perimeters to check how compact they are, taking the area to perimeter ratio of square and circle as exemplar, ideal plan shapes. The lower area/perimeter ratio the lower plan compactness (Table 1). Another check-up was of elevations openings percentages and ratios (Table 2).

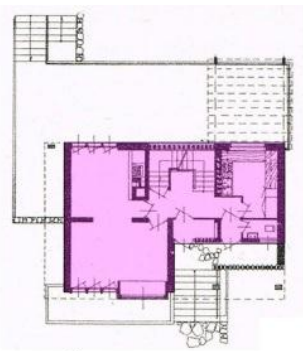

2

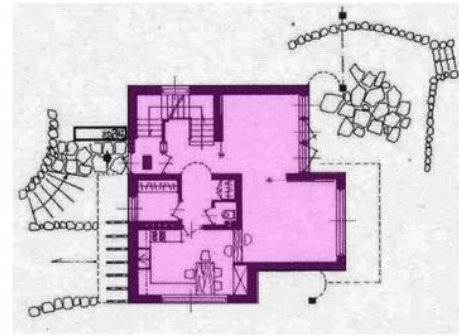

4

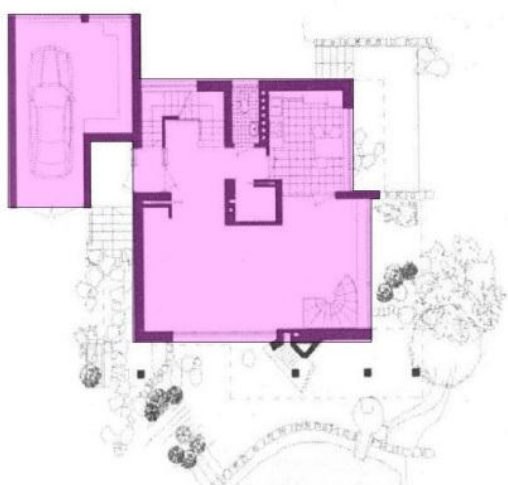

Figure 5. Sample plans of houses designed by Z. Abrahamowicz 1-house 1, 2-house 2, 3-house 3, 4-house 4, 5-house 5, 6house 6 
Table 1. Plan compactness of selected houses

\begin{tabular}{cccc}
\hline Item & $\begin{array}{c}\text { Area } \\
{\left[\mathbf{m}^{2}\right]}\end{array}$ & $\begin{array}{c}\text { Perimeter } \\
{[\mathbf{m}]}\end{array}$ & $\begin{array}{c}\text { Area / Perimeter } \\
\text { ratio }\end{array}$ \\
\hline Square & 69,03 & 33,23 & 2,07 \\
\hline Circle & 54,21 & 26,1 & 2,07 \\
\hline House 1 & 67,34 & 37,48 & 1,8 \\
\hline House 2 & 48,46 & 31,35 & 1,55 \\
\hline House 3 & 88,82 & 39,9 & 2,22 \\
\hline House 4 & 71,57 & 36,22 & 1,97 \\
\hline House 5 & 117,53 & 51,83 & 2,27 \\
\hline
\end{tabular}

Table 2. Elevation openings ratio of selected houses

\begin{tabular}{|c|c|c|c|}
\hline Item & $\begin{array}{l}\text { Elevation } \\
\text { area }\left[\mathrm{m}^{2}\right]\end{array}$ & $\begin{array}{l}\text { Openings } \\
\text { area }\left[\mathrm{m}^{2}\right]\end{array}$ & $\begin{array}{c}\text { Openings } \\
\text { percentage }\end{array}$ \\
\hline House 1 & 266,4 & 39,97 & $15 \%$ \\
\hline House 2 & 254,84 & 55,08 & $21,61 \%$ \\
\hline House 3 & 409,77 & 68,68 & $16,76 \%$ \\
\hline House 4 & 417,38 & 60,51 & $14,5 \%$ \\
\hline House 5 & 474,38 & 86,68 & 18,27 \\
\hline
\end{tabular}

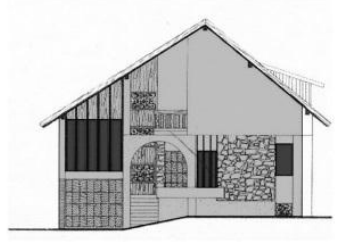

1

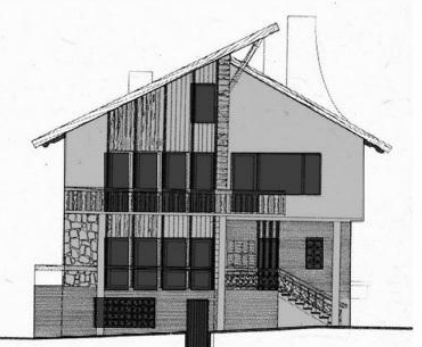

3

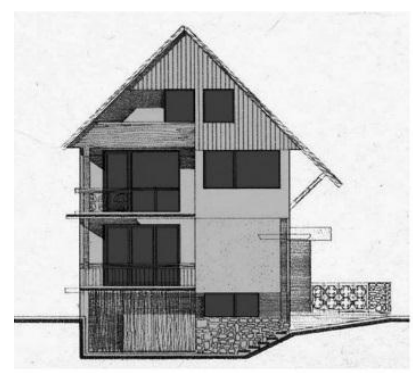

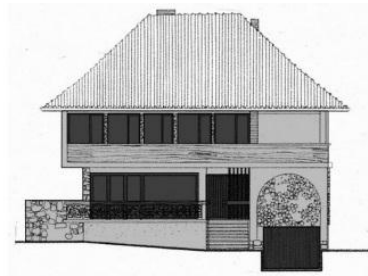

2
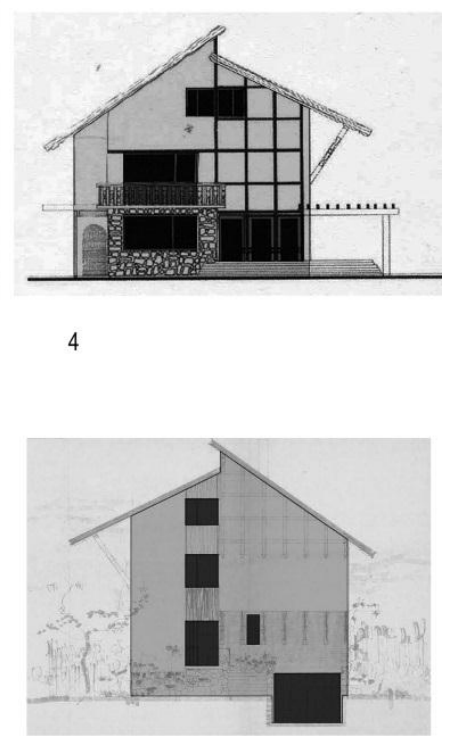

Figure 6. Sample elevations of houses designed by $\mathrm{Z}$. Abrahamowicz 1-house 1, 2-house 2, 3-house 3, 4-house 4, 5-house 5, 6-house 6

\section{7. (WHAT IS) A SUSTAINABLE BUILDING}

Below I listed the most important characteristics of sustainable building that appear in twentieth century's and present discourse of sustainable architecture.

- A sustainable building sustains and develops the structure of the city, the scale, the materials.
- A sustainable building is a building, which is accepted by and serves the society.

- A sustainable building is a building, which has social and cultural value.

- A sustainable building is a building, which gains value with time.

- A sustainable building is a building, which is easy to adapt to other than original use(s).

- A sustainable building is flexible, adaptable, open-ended.

- A sustainable building is not specific; it has a potential to be something else than it was conceived as.

- A sustainable building is resource efficient, does not spend and waste too much of materials and energy.

- A sustainable building is a building, which has a life span of more than 100 years.

According to Prof. Dietmar Eberle, the biggest contribution architects can do for the sustainability and for performance of the building is to design and build buildings, which will have a lifetime of more than 100 years [10]. Mies van der Rohe universal building idea is in fact the formula of a sustainable building. The principle of programmatic uncertainty of architecture meant that only function in case of long-living building - that is working, serving the society - is a function of flexibility of use through the lifetime of the building. Therefore, the only type of a building, which makes sense in terms of functionality is a building which is not suited to any specific function [11].

According to Adam Caruso of Caruso St John Architects great buildings of the past, especially second half of nineteen century and early twentieth century - buildings which were modern, but not necessarily modernist have a great deal of this sort of sustainability. They might be built as housing but they really work well as offices or schools, they might be factories once and they become work space and lofts or whatever, a museum, and all of these things are possible. That physical thing, which was built with a particular intention has all of this other potential in it [12].

\section{NEW USES AND ALTERATIONS ABRAHAMOWICZ'S BUILDINGS}

The programmatic organization of the building is a system, which has a lifespan of less than 20 years. Therefore, it is of great importance that valuable buildings have a potential to accommodate changes of the programmatic organization [10]. Below is a short survey of changes of uses or alterations to buildings designed by Zbigniew Abrahamowicz.

1. Actor's House initially was designed as a small hotel for artists visiting Szczecin in groups or individually. After few decades this type of state-financed institution became obsolete and the building got sold and rebuild for a new use as apartments block.

2. House of Irena Brodzińska - the house was sold and at the moment is a home for insurance company branch. It's flexible, open plan ground floor allowed to adopt it well to

new office function. It's excellent location on one of the city's longest arteries, near parks and recreation areas is only a bonus for the business.

3. Amphitheater - since it's opening in 1975, it has been in almost constant use. Its roof has been replaced in 2000 and in 2015 there was an architectural competition held for ideas to redesign existing roof, backstage and audience. The competition brief called for design proposals to maximize the 
flexibility of the amphitheater for a variety of performances on the stage and to add a new roof to cover both stage as well as audience. According to the brief amphitheater together with its immediate surroundings was defined as contemporary cultural heritage and it was recommended to respect the original design guidelines as much as possible [13]. The competition was won by a British architectural office Flanagan Lawrence Architects based in London. The chosen project proposed the roof, which is structurally independent of the existing arch, and is formed by a curved truss which serves as the edge beam to a single cable net structure. This net supports a series of inflated fabric roof panels and suspended lighting arrays (...) The back of the stage is enclosed by curved glazed screens, which offer picturesque views out to Rusatka Lake and create a scenic backdrop to performances [14]. The project includes upgrade of 2500 seat auditorium, refurbishment of existing backstage area and addition of facilities such as box office, toilets and a café. The restoration and construction of the new enclosure was due to start on site in 2019, and finish early 2020. In the beginning of 2020 building works haven't started yet.

4. Flower Shop on Odrawąż Street, near the Szczecin Town Hall was rebuild to become a small pizzeria.

5. Wedding Palace - was adapted to become a headquarters of political party. The birch tree, which the building literally embraced generously, was cut down in the times of ecological alert, and buzz being raised every time a tree in the city is removed.

6. Fountain Avenue - since it's opening in the seventies it was refurbished and populated by additional pavilions with cafes and restaurants, the fountains themselves were upgraded and renewed.

\section{CONCLUSIONS}

To conclude, there is at least two general ways of understanding sustainability: one is about keeping ecological equilibrium and the other is about continuity. In times of Abrahamowicz professional activity: from about 1965 to his premature death in 1990 - term 'sustainability' was not present in architectural discourse in Poland but we can find the traces of actual sustainability in any of his work. Notions like continuity of urban tissue, blending with existing surroundings, enriching architecture with art and finally making buildings that last. His houses and especially public buildings are still serving its purposes, some of them are upgraded and, what is perhaps more important, are popular and loved by people of Szczecin.

\section{REFERENCES}

[1] Bal, W., Dawidowski, R., Raczyński, M., Sietnicki, M. Szymski, A.M. (2007). Architektura polska lat 19611975 na obszarze Pomorza Zachodniego. Szczecin, 159.

[2] Szymski, A.M. (2001). Architektura i architekci Szczecina (1945-1995): architektura Szczecina na tle osiagnięć polskiej architektury współczesnej (próba syntezy). Prace Naukowe Politechniki Szczecińskiej. Instytut Architektury i Planowania Przestrzennego, 560(41): 9-340.

[3] Excerpt of Janusz Kruszelnicki Interview. (1996). In Zbigniew Abrahamowicz Architekt, TVP S.A. Szczecin.

[4] Sachanowicz, T. (2019). Twórczość Zbigniewa Abrahamowicza na tle architektury Szczecina w latach 1945-1989. Studia z Architektury Nowoczesnej, 6(2018). https://doi.org/10.11588/.2018.6.61598

[5] Architecture of The Vii Day: The Latest Architecture and News. https://www.archdaily.com/tag/architecture-of-the-viiday, accessed on Aug 23, 2019.

[6] Rybczyński, W. (2014). How Architecture Works: A Humanist's Toolkit. Cracow, Farrar, Straus and Giroux.

[7] Nekanda-Trepka, J. (2006). Kościoł pw. św. Krzyża. Szczecin - Pogodno, Szczecin.

[8] Excerpt of Kazimierz Stachowiak interview in Zbigniew Abrahamowicz Architekt, TVP S.A. Szczecin, 1996, www.youtube.com, online, https://www.youtube.com/watch?v=3j4u8hGJlt8\&t=36 4s, accessed on Aug. 23, 2019.

[9] Łopuch, M. (2010). Szczecin Pogodno. Szczecin, 400402.

[10] Interview with Dietmar Eberle: What is architecture? www.youtube.com, online, https://www.youtube.com/watch?v=ECdjLA5mBGw, accessed on Aug. 23, 2019.

[11] Blake, P. (1964). Mies van der Rohe. Architecture and Structure. Penguin Books: Harmondsworth, 87-88.

[12] Interview with Adam Caruso: Adam Caruso: Novelty is Nonsense, Louisiana Channel, www.youtube.com, online, https://www.youtube.com/watch?v=Jyfq7uLNXg. accessed on Aug. 23, 2019.

[13] SARP competition brief for rebuilding of The Summer Theatre named after Helena Majdaniec in Szczecin, 2015; online: http://szczecin.sarp.org.pl/teatrletni/pliki/regulamin.pdf

[14] Flanagan Lawrence Architects website, online, https://www.flanaganlawrence.com, accessed on Aug. $23,2019$. 